\title{
ANALISIS FAKTOR-FAKTOR YANG MEMPENGARUHI PEMILIHAN KARIR MENJADI AKUNTAN PUBLIK OLEH MAHASISWA PROGRAM STUDI AKUNTANSI STIE AKA SEMARANG
}

\author{
Yetti Iswahyuni \\ Iswahyuni23061976@gmail.com \\ STIE AKA Semarang
}

\begin{abstract}
ABSTRAK
Indonesia sangat kekurangan tenaga profesional akuntan. Sehubungan dengan hal tersebut, maka diberlakukannya UU No.5 tahun 2011 yang menyatakan bahwa, lulusan dari program studi non akuntansi dapat berprofesi sebagai akuntan publik asalkan lulus ujian sertifikasi, diharapkan mampu membuat mahasiswa dapat mengetahui seperti apakah itu profesi akuntan, dan apakah terdapat faktor-faktor pendorong untuk memilih profesi akuntan tersebut. Penelitian ini bertujuan menguji pengaruh faktor-faktor pendorong yang diduga mempengaruhi pemilihan karir sebagai akuntan publik meliputi penghargaan finansial, pelatihan profesional, nilai-nilai sosial, lingkungan kerja dan pertimbangan pasar kerja.

Populasi yang digunakan dalam penelitian ini adalah seluruh mahasiswa akuntansi STIE AKA Semarang. Adapun yang menjadi sampel adalah 76 mahasiswa program studi akuntansi. Teknik pengambilan sampel dalam penelitian ini menggunakan purposive sampling. Alat analisis yang digunakan adalah analisis regresi linier berganda. Hasil pengujian menunjukkan bukti empiris bahwa : Faktor finansial dan persaingan pasar kerja tidak berpengaruh terhadap pemilihan karir sebagai akuntan publik bagi mahasiswa akuntansi STIE AKA Semarang. Pelatihan profesional, lingkungan kerja dan nilai-nilai sosial berpengaruh terhadap pemilihan karir sebagai akuntan publik bagi mahasiswa akuntansi STIE AKA Semarang.
\end{abstract}

Kata kunci : Penghargaan Finansial, Persaingan, Akuntan Publik.

\section{PENDAHULUAN}

Karir dalam bidang akuntansi cukup banyak antara lain akuntan publik, akuntan perusahaan, akuntan pemerintah, akuntan pendidik dan profesi non akuntan. Sarjana akuntansi memiliki berbagai macam pertimbangan untuk karir apa yang dijalani. Akuntansi memegang peranan penting dalam ekonomi dan sosial, karena setiap keputusan yang bersifat keuangan harus berdasarkan informasi akuntansi. Keadaan ini menjadikan akuntan sebagai profesi yang sangat dibutuhkan keberadaannya dalam lingkungan organisasi bisnis. Keahlian khusus seperti pengelolaan data bisnis menjadi informasi berbasis komputer, pemeriksaan keuangan maupun non keuangan. Namun sarjana akuntansi bisa juga memiliki keahlian di luar bidangnya, seperti dalam hal pemasaran produk dan lain sebagainya. Munculnya anggapan bahwa sarjana akuntansi harus berkarir sebagai akuntan, menjadi salah satu alasan sarjana akuntansi kurang memiliki wawasan dan minat untuk mencari peluang karir yang lain, selain menjadi akuntan. Banyak sarjana akuntansi memilih alternatif karir saat mereka lulus kuliah. Setuju atau tidak, empat tahun (atau lebih) berada di lingkungan pendidikan tidak selalu membuat mereka mengerti apa yang ingin mereka lakukan. Lebih buruk lagi jika mereka tidak banyak berkecimpung di dunia organisasi ataupun ekstrakurikuler. Semakin sedikit hal yang mereka ketahui. Biasanya mereka memiliki dua pilihan dalam penentuan 
karirnya, pertama adalah menciptakan pekerjaan sendiri (wiraswasta), sementara kedua adalah mencari kerja sebagai karyawan.

Saat ini banyak lulusan akuntansi terbaik dari perguruan-perguruan tinggi tidak lagi memilih karir sebagai akuntan publik sebagai jalur pilihan karir yang utama bagi mereka. Dengan tingkat persaingan yang tinggi dan bahkan mungkin tingkat kemampuan dan keahlian masing-masing tidak menutup kemungkinan mereka akan berkarir di luar bidang akuntansi lainnya yang mungkin masih berhubungan dengan keuangan seperti wirausaha, konsultan keuangan dan lain sebagainya.Wijayanti (2001) yang dimuat dalam Dian Putri Merdekawati (2011) menyatakan bahwa pilihan karir mahasiswa akuntansi dipengaruhi oleh beberapa faktor, seperti penghargaan finansial atau gaji, pelatihan profesional, pengakuan profesional, nilai-nilai sosial, lingkungan kerja dan kemudahan mengakses lowongan pekerjaan. Nugraha Adi Putra (2012) menyatakan kecenderungan saat ini adalah banyak mahasiswa yang tidak mengetahui dengan pasti tentang pemilihan profesi mereka. Lingkungan luar yang berubah terlalu cepat memaksa mereka memodifikasi keputusan mereka dari waktu ke waktu. Hal ini sepertinya disebabkan oleh kurangnya pengenalan terhadap metode-metode bimbingan dan penilaian profesi sewaktu di bangku kuliah. Nugraha Adi Putra (2012) juga menambahkan persepsi mahasiswa akuntansi mengenal faktor-faktor yang mempengaruhi mereka dalam memilih profesi, baik secara keseluruhan maupun berdasarkan gendernya, maka setiap mahasiswa akuntansi yang akan terjun ke dalam dunia bisnis dapat dengan tepat memilih profesi yang akan relevan dengan tuntutan dunia kerja, sehingga mahasiswa akuntansi yang sudah lulus dan siap terjun dalam dunia kerja lebih mudah menyesuaikan kemampuan yang dimilikinya dengan tuntutan dalam pekerjaan. Mengingat profesi akuntan pada masa yang akan datang menghadapi tantangan yang semakin berat, maka kesiapan yang akan menyangkut profesi mutlak diperlukan.

Seiring dengan diberlakukannya UU No.5 tahun 2011 yang menyatakan bahwa, para sarjana non akuntansi dapat berprofesi sebagai akuntan publik asalkan lulus ujian sertifikasi. Hal tersebut berarti bahwa dapat mengancam para sarjana program studi akuntansi, dimana untuk menjadi akuntan publik mereka harus bersaing dengan lulusan program studi non akuntansi. Hal ini disebabkan karena pertumbuhan akuntan di Indonesia sangat lambat. Sampai dengan saat ini Indonesia sangat kekurangan tenaga profesional akuntan publik. Jumlah wajib audit yang ada di Indonesia seiring makin meningkatnya ekonomi dan munculnya perusahaan-perusahaan/lembaga baru serta makin berkembangnya perusahaan/lembaga yang sudah ada. Hal ini sangat tidak sebanding dengan jumlah akuntan publik yang ada. Padahal akuntan publik sangat berperan penting dan strategis bagi perusahaan swasta dan lembaga publik lainnya. Akuntan publik sangat menentukan kualitas laporan keuangan yang akan berkontribusi pada penetapan kebijakan-kebijakan keuangan yang pada akhirnya dapat berpengaruh pada perekonomian negara. Berdasarkan latar belakang yang telah diuraikan di atas maka rumusan masalah dalam penelitian ini adalah apakah penghargaan finansial, pelatihan profesional, nilai-nilai sosial, lingkungan kerja dan pertimbangan pasar kerja berpengaruh terhadap pemilihan karir sebagai akuntan publik bagi mahasiswa akuntansi STIE AKA Semarang. Berdasarkan permasalahan penelitian tersebut, tujuan penelitian ini adalah untuk menguji pengaruh penghargaan finansial, pelatihan profesional, nilai-nilai sosial, lingkungan kerja dan pertimbangan pasar kerja berpengaruh terhadap pemilihan karir sebagai akuntan publik bagi mahasiswa akuntansi STIE AKA Semarang.

\section{TINJAUAN TEORI DAN PENGEMBANGAN HIPOTESIS}

\section{Teori Motivasi}

Pemilihan suatu profesi oleh individu berhubungan dengan teori motivasi. Salah seorang ilmuwan yang dipandang sebagai pelopor teori motivasi adalah Abraham H. Maslow. 
Hasil-hasil pemikirannya tertuang dalam bukunya yang berjudul "Motivation and Personality." Teori motivasi yang dikembangkan pada tahun 40-an itu pada intinya berkisar pada pendapat bahwa manusia mempunyai lima tingkat atau hierarki kebutuhan (Maslow's Need Hierarcy), yaitu:

1. Kebutuhan fisiologikal, seperti sandang, pangan dan papan.

2. Kebutuhan keamanan, tidak hanya dalam arti fisik, akan tetapi juga mental, psikologikal dan intelektual.

3. Kebutuhan sosial.

4. Kebutuhan penghargaan yang pada umumnya tercermin dalam berbagai simbol-simbol status.

5. Aktualisasi diri dalam arti tersedianya kesempatan bagi seseorang untuk mengembangkan potensi yang terdapat dalam dirinya sehingga berubah menjadi kemampuan nyata.

Kebutuhan manusia digolongkan sebagai rangkaian dan bukan sebagai hierarki. Dalam hubungan ini perlu ditekankan bahwa:

a. Kebutuhan yang satu saat sudah terpenuhi sangat mungkin akan timbul lagi di waktu yang akan datang.

b. Pemuasan berbagai kebutuhan tertentu, terutama kebutuhan fisik, bisa bergeser dari pendekatan kuantitatif menjadi kualitatif dalam pemuasannya.

c. Berbagai kebutuhan tersebut tidak akan mencapai "titik jenuh" dalam arti tibanya suatu kondisi dalam mana seseorang tidak dapat lagi berbuat sesuatu dalam pemenuhan kebutuhan itu.

Menurut Komaruddin (1994) pada dasarnya motivasi dibagi menjadi 2 jenis utama yaitu motivasi intrinsik (motivasi yang timbul dari dalam diri seseorang) dan motivasi ekstrinsik (motivasi yang timbul disebabkan faktor dari luar diri seseorang). Menurut Supardi dan Anwar (2004) motivasi adalah keadaan dalam diri seorang yang mendorong keinginan individu untuk melakukan kegiatan-kegiatan tertentu guna mencapai tujuan. Menurut Sembiring (2009), motivasi sangat penting dimiliki setiap individu dalam dirinya karena motivasi menyebabkan individu mau bekerja dengan giat dan antusias mencapai hasil yang optimal. Menurut Robbins dalam Wicaksono (2011), motivasi adalah proses yang ikut menentukan intensitas arah dan ketekunan individu dalam usaha mencapai sasaran.

Menurut Gibson dan Aprilyan (2011) motivasi merupakan konsep yang menguraikan tentang kekuatan-kekuatan individu untuk memulai dan mengarahkan perilakunya terhadap pekerjaan tertentu.

\section{Pemilihan Karir Sebagai Akuntan Publik Bagi Mahasiswa Akuntansi STIE AKA Semarang}

Yudhantoko (2013) menyatakan seorang mahasiswa akuntansi tertarik pada suatu karir untuk dikejar di masa depan adalah disebabkan karena karir tersebut dianggap memiliki suatu nilai yang memberikan kepuasan pribadi. Dalam proses pemilihan karir, mahasiswa akuntansi akan membentuk perilaku atau usaha-usaha yang maksimal guna mendapatkan hasil yang diinginkannya.

Kuningsih (2012) pada 129 responden mahasiswa dari S1, S2 dan PPA rata-rata mahasiswa memilih jurusan akuntansi, didorong keinginan mereka menjadi akuntan. Keadaan bahwa akuntan di Indonesia masih banyak dibutuhkan oleh perusahaan go public ataupun belum. Ini dibuktikan $75 \%$ responden memilih akuntansi karena banyak dibutuhkan dan $25 \%$ responden tertarik karena berhubungan dengan keuangan.

\section{Konsep Karir}

Kunartinah (2003) menyatakan karir dapat dilihat dari berbagai cara, sebagai berikut:

1. Posisi yang dipegang individu dalam suatu jabatan di suatu perusahaan dalam kurun waktu tertentu.

2. Dalam kaitannya dengan mobilitas dalam suatu organisasi. 
3. Tingkat kemapanan kehidupan seseorang setelah mencapai tingkatan umur tertentu yang ditandai dengan penampilan dan gaya hidup seseorang.

Dalam pengembangan suatu karir, terdapat tahap-tahap yang dilalui oleh seseorang (Kunartinah, 2003):

1. Tahap pilihan karir (career choice)

Tahap pilihan karir secara umum terjadi antara masa remaja dari umur 15 sampai 22 tahun, ketika manusia mengembangkan visi dan identitas mereka yang berkenaan dengan masa depan atau gaya hidup, sesuai dengan pilihan jurusan dan pendidikan seseorang.

2. Tahap karir awal (early career)

Tahap karir awal terjadi umur 22-38 tahun. Seseorang juga meninjau kembali pengalaman yang terdahulu dan sekarang selama bekerja di perusahaan dan mencoba untuk menentukan apa yang diharapkan di masa yang akan datang.

3. Tahap karir pertengahan (middle career)

Tahap karir pertengahan terjadi umur 38-55 tahun, seseorang bergerak dalam suatu periode stabilisasi di mana mereka dianggap produktif, menjadi semakin memikul tanggung jawab yang lebih berat dan menerapkan suatu rencana lahir yang lebih jangka panjang.

4. Tahap karir akhir dan pensiun

Tahap karir akhir dan pensiun terjadi umur 55-67 tahun, merupakan tahap terakhir dalam tahapan karir. Seseorang mulai melepaskan diri dari belitan-belitan tugasnya dan bersiap pensiun. Tahapan ini juga berguna untuk melatih penerus, mengurangi beban kerja atau mendelegasikan tanggung jawab kepada karyawan baru atau junior.

Tahap ini memiliki 2 fase, yaitu:

a. Fase maintenance pada umur 55-62 tahun, mengalami gairah kerja yang semakin bertambah pada fase ini. Kreatifitas muncul, ide-ide baru untuk memperbaiki organisasi melintas dalam pikiran. Vitalitas orang semakin bertambah dalam pekerjaan fase ini. Self actualizationsemakin matang dan mulai mempersiapkan diri untuk memasuki fase terakhir.

b. Fase withdrawal yang terjadi pada umur 62-70 tahun. Pada fase ini orang mulai memikirkan bagaimana meneruskan karir yang sudah dibangun atau perusahaan yang sudah dirintis dan berjalan. Seseorang mulai memikirkan siapa yang akan menggantikannya di kemudian hari. Melakukan regenerasi kepemimpinan kepada junior-juniornya untuk meneruskan pekerjaan yang sebelumnya. Pada fase ini seseorang mulai memikirkan bagaimana agar apa yang sudah dimulai dan

\section{HIPOTESIS} berjalan bisa diteruskan dalam jalan yang benar oleh penerusnya.

\section{Penghargaan Finansial Terhadap Pemilihan Karir Sebagai Akuntan Publik Bagi Mahasiswa Akuntansi STIE AKA Semarang}

Penghargaan finansial merupakan imbalan timbal balik atas pemberian jasa, tenaga, usaha dan manfaat seseorang dalam suatu ikatan pekerjaan. Penghargaan finansial yang besar diyakini sebagai daya tarik bagi setiap pekerja. Akuntan publik dalam kenyataannya mengaudit tidak hanya satu perusahaan saja, namun biasanya dua atau lebih perusahaan dalam sekali tempo. Semakin besar perusahaan yang menggunakan jasa akuntan publik, maka pendapatan yang akan diterima akan semakin tinggi. Berkarir di Kantor Akuntan Publik dapat menghasilkan pendapatan yang tinggi dibandingkan dengan pendapatan yang diperoleh dari karir yang lain. Oktavia (2005) dan Aprylian (2011) menyatakan bahwa berkarir di Kantor Akuntan Publik (KAP) merupakan suatu karir yang memberikan penghargaan secara finansial dan pengalaman bekerja yang bervariasi. Berdasarkan penjelasan di atas dapat disimpulkan hipotesis: Penghargaan finansial berpengaruh terhadap pemilihan karir sebagai akuntan publik bagi mahasiswa akuntansi STIE AKA Semarang. 


\section{Pelatihan Profesional Terhadap Pemilihan Karir Sebagai Akuntan Publik Bagi Mahasiswa Akuntansi STIE AKA Semarang}

Pendidikan formal saja tidak cukup untuk bekerja di Kantor Akuntan Publik, namun juga harus ditunjang oleh pengalaman praktek di lapangan dengan jam kerja yang memadai. Pelatihan profesional sangat dibutuhkan untuk menunjang karir sebagai akuntan publik. Pelatihan profesional ini meliputi: pelatihan sebelum bekerja, mengikuti pelatihan di luar lembaga, mengikuti pelatihan rutin di Lembaga. Menurut Stolle (1976) dalam Mariny (2003) pelatihan dipertimbangkan mahasiswa yang memilih karir akuntan publik. Hal ini membuktikan bahwa memilih karir tidak hanya bertujuan mencari penghargaan finansial, tetapi juga ada keinginan untuk berprestasi dan mengembangkan diri. Berdasarkan penjelasan di atas dapat disimpulkan hipotesis: Pelatihan profesional berpengaruh terhadap pemilihan karir sebagai akuntan publik bagi mahasiswa STIE AKA Semarang.

\section{Nilai-Nilai Sosial Terhadap Pemilihan Karir Sebagai Akuntan Publik Bagi Mahasiswa Akuntansi STIE AKA Semarang}

Nilai-nilai sosial berkaitan dengan pandangan masyarakat terhadap nilai-nilai sosial dari suatu karir yang dipilih. Nilai-nilai sosial adalah nilai seseorang dari sudut pandang orang lain di lingkungannya. Aprilyan (2011) mengungkapkan bahwa nilai-nilai sosial dipertimbangkan oleh mahasiswa akuntansi dalam memilih profesi yang meliputi: kesempatan berinteraksi, kepuasan pribadi, kesempatan untuk menjalankan hobi dan perhatian perilaku individu. Berdasarkan penjelasan di atas dapat disimpulkan hipotesis: Nilai-nilai sosial berpengaruh positif terhadap pemilihan karir sebagai akuntan publik bagi mahasiswa akuntansi STIE AKA Semarang.

\section{Lingkungan Kerja Terhadap Pemilihan Karir Sebagai Akuntan Publik Bagi Mahasiswa Akuntansi STIE AKA Semarang}

Lingkungan kerja berkaitan dengan kondisi dari suatu pekerjaan yang meliputi karakteristik dan beban-beban yang dihasilkan dari pekerjaan tersebut. Kondisi atau suasana yang terdapat pada suatu pekerjaan dapat memberikan dampak dalam kinerja dari pekerja. Lingkungan kerja merupakan suasana kerja yang meliputi sifat kerja (rutin, atraktif dan sering lembur), tingkat persaingan antar karyawan dan tekanan kerja merupakan faktor dari lingkungan kerja. Rahayu juga mengungkapkan bahwa mahasiswa yang memilih profesi akuntan publik menganggap bahwa profesi yang mereka pilih akan memberikan banyak kesempatan untuk berkembang. Karir sebagai akuntan publik dianggap karir yang jenis pekerjaannya tidak rutin, lebih atraktif dan banyak tantangannya, tidak dapat dengan cepat terselesaikan. Ramadani (2013) mengungkapkan bahwa karakter yang keras dan komitmen dibutuhkan oleh seorang akuntan dalam menghadapi lingkungan pekerjaan, seorang pekerja dituntut untuk dapat beradaptasi dan bersosialisasi dengan lingkungan kerja, agar dapat mencapai target kerja yang diwajibkan. Berdasarkan penjelasan di atas dapat disimpulkan hipotesis: Lingkungan kerja berpengaruh terhadap pemilihan karir sebagai akuntan publik bagi mahasiswa akuntansi STIE AKA Semarang.

\section{Pertimbangan Pasar Kerja Terhadap Pemilihan Karir Sebagai Akuntan Publik Bagi Mahasiswa Akuntansi STIE AKA Semarang}

Pertimbangan pasar kerja meliputi keamanan kerja dan tersedianya lapangan kerja atau kemudahan mengakses lowongan kerja. Keamanan kerja merupakan faktor yang menyebabkan karir yang dipilih dapat bertahan dalam jangka waktu yang cukup lama dan jauh dari kasus PHK. Hasil penelitian Rasmini (2007) menunjukkan bahwa mahasiswa menganggap karir sebagai akuntan publik mampu memberikan keamanan kerja yang lebih 
terjamin. Hasil penelitian Sembiring (2009) menunjukkan bahwa pertimbangan pasar kerja berpengaruh terhadap minat mahasiswa menjadi akuntan publik. Berdasarkan penjelasan di atas dapat disimpulkan hipotesis: Pertimbangan pasar kerja berpengaruh terhadap pemilihan karir sebagai akuntan publik bagi mahasiswa akuntansi STIE AKA Semarang.

\section{METODE PENELITIAN}

Populasi Populasi yang digunakan dalam penelitian ini adalah seluruh mahasiswa akuntansi STIE AKA Semarang. Adapun yang menjadi sampel adalah 76 mahasiswa program studi akuntansi. Teknik pengambilan sampel dalam penelitian ini menggunakan purposive sampling.Variabel yang digunakan dalam penelitian ini adalah variabel independen dan dependen. Dalam penelitian ini variabel independen yang digunakan adalah penghargaan finansial, pelatihan profesional, nilai-nilai sosial, lingkungan kerja dan pertimbangan pasar kerja dan variabel dependen yang digunakan adalah pemilihan karir sebagai akuntan publik bagi mahasiswa STIE AKA Semarang.

Tabel 3.1. Variabel Penelitian dan Definisi Operasional

\begin{tabular}{lll}
\hline No & Variabel & Indikator pengukuran variabel \\
\hline 1. & $\begin{array}{l}\text { Gaji/penghargaan } \\
\text { finansial }\end{array}$ & $\begin{array}{l}\text { Gaji awal yang tinggi, } \\
\text { Ada dana pensiun, } \\
\text { Kenaikan gaji yang diberikan lebih. }\end{array}$ \\
& & \multicolumn{1}{c}{$\begin{array}{l}\text { Adanya pelatihan kerja sebelum mulai bekerja, } \\
\text { Adanya pelatihan di luar lembaga untuk } \\
\text { meningkatkan profesional, } \\
\text { Pdanya pelatihan rutin di dalam lembaga, } \\
\text { profesional }\end{array}$} \\
& $\begin{array}{l}\text { Dapat memperoleh pengalaman kerja yang } \\
\text { bervariasi. }\end{array}$
\end{tabular}

3. Nilai-nilai sosial Pemberikan kesempatan untuk melakukan kegiatan sosial,

Perlu kesempatan untuk berinteraksi dengan orang lain,

Perlu kesempatan untuk menjalankan hobi,

Lebih memberikan kepuasan pribadi,

Merupakan pekerjaan yang lebih bergengsi dibanding karir yang lain,

Memperhatikan perilaku individu,

Adanya kesempatan untuk bekerja dengan ahli di bidang lain.

4. Lingkungan kerja Lingkungan pekerjaan rutin,

Lingkungan pekerjaan lebih banyak tantangan,

Pekerjaan yang lebih cepat diselesaikan,

Lingkungan kerja yang menyenangkan,

Sering lembur,

Ada tekanan kerja untuk mencapai hasil yang sempurna. 


\begin{tabular}{lll}
\hline 5. & Pertimbangan pasar \\
kerja & Keamanan kerja yang lebih terjamin, \\
& Lapangan kerja yang ditawarkan mudah diketahui.
\end{tabular}

Sumber: Rahayu (2003)

\section{Teknik Analisis Data dan Pengujian Hipotesis}

Alat analisis yang digunakan dalam penelitian ini yaitu analisis regresi berganda. Analisis regresi berganda digunakan untuk menentukan signifikasi pengaruh penghargaan finansial, pelatihan profesional, nilai-nilai sosial, lingkungan kerja danpertimbangan pasar kerja terhadap pemilihan karir sebagai akuntan publik bagi mahasiswa STIE AKA Semarang. Pengujian regresi linear berganda dapat dilakukan setelah model dalam penelitian ini memenuhi syarat-syarat validitas, reliabilitas dan uji kelayakan model (uji F).

Model persamaan regresi yang digunakan untuk menguji hipotesis dalam penelitian ini adalah: $Y=\alpha+b_{1} X_{1}+b_{2} X_{2}+b_{3} X_{3}+b_{4} X_{4}+b_{5} X_{5}+e$

\section{PEMBAHASAN HASIL PENELITIAN}

Sebelum melakukan pengujian Hipotesis terlebih dahulu dilakukan uji kualitas data berupa Uji Validitas dan Uji Reliabilitas, semua data yang digunakan telah lolos Uji Validitas dan Uji Reliabilitas. Penelitian ini juga telah memenuhi syarat untuk dilakukan pengujian secara regresi berganda.

Tabel Koefisien Regresi

Coefficients $^{\mathrm{a}}$

\begin{tabular}{|c|c|c|c|c|c|c|}
\hline \multirow[b]{2}{*}{ Mode } & & \multicolumn{2}{|c|}{$\begin{array}{l}\text { Unstandardized } \\
\text { Coefficients }\end{array}$} & \multirow{2}{*}{$\begin{array}{c}\text { Standardized } \\
\text { Coefficients } \\
\text { Beta }\end{array}$} & \multirow[b]{2}{*}{$\mathrm{t}$} & \multirow[b]{2}{*}{ Sig. } \\
\hline & & B & Std. Error & & & \\
\hline \multirow[t]{6}{*}{1} & (Constant) & -2.568 & .473 & & -5.426 & .000 \\
\hline & Gaji & .240 & .176 & .144 & 1.364 & .177 \\
\hline & Pelatihanprofesional & .358 & .170 & .226 & 2.105 & .039 \\
\hline & Nilainilaisosial & .367 & .183 & .208 & 2.009 & .048 \\
\hline & Lingkungankerja & .575 & .138 & .313 & 4.178 & .000 \\
\hline & Pertimbanganpasarkerja & .193 & .145 & .134 & 1.335 & .186 \\
\hline
\end{tabular}

a. Dependent Variable: Kariryangdiinginkan

Sumber: Data output SPSS 23, tahun 2017.

\section{Penghargaan Finansial Terhadap Pemilihan Karir Sebagai Akuntan Publik Bagi Mahasiswa Akuntansi STIE AKA Semarang}

Hasil regresi linier berganda menunjukkan tingkat signifikansi 0,177 yang berarti penghargaan finansial tidak berpengaruh secara signifikan terhadap pemilihan karir sebagai akuntan publik bagi mahasiswa akuntansi STIE AKA Semarang. Menurut peneliti faktor penghargaan finansial bagi lulusan akuntan yang (fresh graduate) tidak menjadi pertimbangan utama, tetapi memperoleh kesempatan kerja dan ingin memiliki pengalaman yang bervariasi dalam bekerja menjadi pertimbangan utama untuk berkarir sebagai akuntan publik. Sejalan dengan hasil penelitian Chan tahun 2012 yang menyimpulkan bahwa mahasiswa yang ingin bekerja sebagai akuntan publik lebih tertarik dengan variasi pengalaman yang akan mereka dapat ketika bekerja. Hasil penelitian Merdekawati tahun 2011 menunjukkan bukti bahwa persepsi mahasiswa terhadap faktor finansial tidak berpengaruh dalam pemilihan karir mereka sebagai akuntan publik atau non akuntan publik. Faktor finansial merupakan faktor yang tidak membedakan secara signifikan terhadap pemilihan profesi akuntan oleh mahasiswa. 
Keinginan memperoleh gaji atau pendapatan tertentu yang sesuai dengan bidang kerja mereka nampaknya bukan menjadi pendorong mahasiswa untuk memilih karir pada salah satu karir akuntan publik. Hal ini karena karir akuntan lain dinilai cukup menjanjikan mendapatkan pendapatan yang besar. Hasil penelitian Sulistyawati tahun 2013 menyimpulkan bahwa karir sebagai akuntan pemerintah memiliki jaminan berupa dana pensiun yang lebih besar dari karir sebagai akuntan publik, akuntan pendidik ataupun akuntan perusahaan. Hasil penelitian ini sesuai dengan penelitian Astami (2001) dan Kunartinah (2003), yang berpendapat bahwa penghargaan finansial tidak berpengaruh signifikan terhadap pemilihan karir.

\section{Pelatihan Profesional Terhadap Pemilihan Karir Sebagai Akuntan Publik Bagi Mahasiswa Akuntansi STIE AKA Semarang}

Hasil regresi linier berganda menunjukkan tingkat signifikansi 0,039 yang berarti pelatihan profesional berpengaruh secara signifikan terhadap pemilihan karir sebagai akuntan publik bagi mahasiswa akuntansi STIE AKA Semarang. Ini terbukti bahwa pendidikan formal saja tidak cukup untuk bekerja di Kantor Akuntan Publik, namun juga harus ditunjang oleh pengalaman praktek di lapangan dengan jam kerja yang memadai. Pelatihan profesional sangat dibutuhkan untuk menunjang karir sebagai akuntan publik. Pelatihan profesional ini meliputi: pelatihan sebelum bekerja, mengikuti pelatihan di luar lembaga, mengikuti pelatihan rutin di Lembaga. Menurut Stolle (1976) dalam Mariny (2003) pelatihan dipertimbangkan mahasiswa yang memilih karir akuntan publik. Hal ini membuktikan bahwa memilih karir tidak hanya bertujuan mencari penghargaan finansial, tetapi juga ada keinginan untuk berprestasi dan mengembangkan diri. Menurut hasil penelitian Merdekawati (2011) menyimpulkan bahwa keinginan menjalankan pekerjaan mereka secara profesional dalam bidang akuntansi nampaknya mendorong mahasiswa memilih profesi yang lebih praktis dan profesional.

\section{Nilai-Nilai Sosial Terhadap Pemilihan Karir Sebagai Akuntan Publik Bagi Mahasiswa Akuntansi STIE AKA Semarang}

Hasil regresi linier berganda menunjukkan tingkat signifikansi 0,048 yang berarti nilai-nilai sosial berpengaruh secara signifikan terhadap pemilihan karir sebagai akuntan publik bagi mahasiswa akuntansi STIE AKA Semarang. Nilai-nilai sosial adalah nilai seseorang dari sudut pandang orang lain di lingkungannya. Pertimbangan nilai sosial yang tinggi justru akan menurunkan pemilihan karir akuntan publik atau mahasiswa akan cenderung memilih karir non akuntan publik. Adanya pengaruh dalam nilai-nilai sosial ini menunjukkan adanya penilaian yang sama bahwa profesi akuntan baik akuntan pemerintah, akuntan perusahaan atau akuntan pendidik memegang nilai-nilai sosial dalam pekerjaan mereka. Peranan pentingnya memegang nilai-nilai sosial bagi semua tingkatan akuntan tersebut karena pentingnya seorang akuntan untuk memegang nilai-nilai sosial yang diakui secara umum, dan hal ini nampaknya harus dipahami oleh semua pilihan karir akuntan. Hasil ini didukung dengan adanya penelitian Merdekawati (2011), Wijayanti (2001), Jumamik (2007) yang mendapatkan hasil variabel nilai-nilai sosial berpengaruh signifikan terhadap pemilihan karir.

\section{Lingkungan Kerja Terhadap Pemilihan Karir Sebagai Akuntan Publik Bagi Mahasiswa Akuntansi STIE AKA Semarang}

Hasil regresi linier berganda menunjukkan tingkat signifikansi 0,000 yang berarti lingkungan kerja berpengaruh secara signifikan terhadap minat menjadi akuntan publik. Faktor lingkungan kerja merupakan pertimbangan utama mahasiswa akuntansi menjadi seorang akuntan publik. Lingkungan yang dinamis dan menyenangkan, bergaul dengan banyak klien dengan pengetahuan dan pengalaman yang bervariasi, menyelesaikan berbagai 
macam kasus audit di berbagai perusahaan dengan ciri khas masing-masing perusahaan membawa daya tarik tersendiri bagi peminat karir akuntan publik rela menjalani semua hambatan karir. Rahayu et al (2003) juga mengungkapkan bahwa mahasiswa yang memilih profesi akuntan publik menganggap bahwa profesi yang mereka pilih akan memberikan banyak kesempatan untuk berkembang. Karir sebagai akuntan publik dianggap karir yang jenis pekerjaannya tidak rutin, lebih atraktif dan banyak tantangannya, tidak dapat dengan cepat terselesaikan. Ramadani (2013) mengungkapkan bahwa karakter yang keras dan komitmen dibutuhkan oleh seorang akuntan dalam menghadapi lingkungan pekerjaan, seorang pekerja dituntut untuk dapat beradaptasi dan bersosialisasi dengan lingkungan kerja, agar dapat mencapai target kerja yang diwajibkan. Hasil penelitian ini sejalan dengan penelitian Rahayu et al (2003) dan Jumamik (2007) yang mendapatkan hasil penelitian variabel lingkungan kerja berpengaruh signifikan terhadap pemilihan karir akuntan publik.

\section{Pertimbangan Pasar Kerja Terhadap Pemilihan Karir Sebagai Akuntan Publik Bagi Mahasiswa Akuntansi STIE AKA Semarang}

Hasil regresi linier berganda menunjukkan tingkat signifikansi 0,186 yang berarti pertimbangan pasar kerja tidak berpengaruh secara signifikan terhadap minat menjadi akuntan publik. Pertimbangan pasar kerja menunjukkan tidak adanya pengaruh signifikan dalam pemilihan karir sebagai akuntan. Hal ini tampaknya terkait dengan keinginan mahasiswa untuk selalu dapat bekerja pada beberapa pekerjaan yang secara prinsip tidak lepas dari bidang akuntansi. Menurut Chan (2012) menyimpulkan mahasiswa yang berminat bekerja sebagai akuntan public sebagian besar terutama ingin mendapatkan pengalaman kerja yang banyak saja dengan kata lain pekerjaan akuntan publik bukan untuk pekerjaan jangka panjang. Pertimbangan pasar kerja menunjukkan tidak adanya pengaruh signifikan dalam pemilihan karir sebagai akuntan, penelitian ini sejalan dengan hasil penelitian Kunartinah (2003), Rahayu et al (2003), Dian Putri Merdekawati (2012).

\section{SIMPULAN, KETERBATASAN DAN SARAN}

Hasil pengujian menunjukkan bukti empiris bahwa: Faktor finansial dan persaingan pasar kerja tidak berpengaruh terhadap pemilihan karir sebagai akuntan publik bagi mahasiswa akuntansi STIE AKA Semarang. Dan Pelatihan profesional, lingkungan kerja dan nilai-nilai sosial berpengaruh terhadap pemilihan karir sebagai akuntan publik bagi mahasiswa akuntansi STIE AKA Semarang. Keterbatasan penelitian ini adalah: a. Hanya mengambil sampel dari mahasiswa program studi akuntansi STIE AKA Semarang. Kondisi ini dapat diartikan bahwa hasil penelitian ini belum bisa digeneralisasikan bagi penelitian dengan wilayah yang sama. $b$. Instrumen penelitian yang digunakan hanya menggunakan kuesioner, sehingga kesimpulan yang diambil hanya berdasarkan pada data yang dikumpulkan melalui kuesioner tersebut. Pada kuesioner penelitian ini untuk non akuntan publik terbagi menjadi akuntan perusahaan, akuntan pemerintah, akuntan pendidik dan non akuntan sehingga dikhawatirkan terdapat hasil yang bias. a. Model penelitian ini hanya menguji faktor-faktor yang sebelumnya telah digunakan dalam penelitian sebelumnya. b.Variabel yang diteliti hanya dapat menjelaskan karir akuntan sebesar $76,5 \%$, sedangkan sisnya diterangkan oleh faktor lain yang tidak diamati dalam penelitian ini. Berdasarkan hasil penelitian yang telah dilakukan, maka saran yang diberikan adalah: 1. Memperbesar sampel penelitian (semua STIE Se-Jateng) sehingga hasil penelitian yang akan datang bisa digeneralisasikan bagi penelitian dengan wilayah yang sama. 2.Riset mendatang sebaiknya menambah dengan pertanyaan terbuka agar dapat mengakomodasi persepsi responden yang belum tersedia dalam kuesioner agar hasil penelitian lebih lengkap. 3.Perlu menambah variabel baru atau menambah variabel yang pernah diteliti pada penelitian terdahulu. 


\section{DAFTAR PUSTAKA}

Andersen, William, dan Chariri, Anis. 2012. Analisis Persepsi Mahasiswa Akuntansi Dalam Memilih Profesi Sebagai Akuntan, Vol.1, No.1: 1-14.

Apriliyan, Lara Absara. 2011. Faktor-Faktor Yang Mempengaruhi Mahasiswa Akuntansi Dalam Pemilihan Karir Menjadi Akuntan Publik. Skripsi. Semarang: Fakultas Ekonomi Universitas Diponegoro.

Asmoro, Tri Kusno Widi dan Suhendro. 2016. Determinan Pemilihan Karir Sebagai Akuntan Publik Oleh Mahasiswa Akuntansi, Jurnal Ekonomi, Vol.1, No.1: 164-178.

Benny, Ellya, dan Yuskar, 2006, "Pengaruh Motivasi Terhadap Minat Mahasiswa Akuntansi Untuk Mengikuti Pendidikan Profesi Akuntansi (PPAk)",Simposium Nasional Akuntansi IX. Padang.

Carl R. Philips and John L. Crain. 1996. "Job Duties and Responsibilities in Public Accounting: Are Student Expectations Unrealistic?.” Journal of Education, Vol 38 Number 9, pp 21-26, MCB University Press ISSN 0040-0912 Available at (www.google.com).

Carpenter, C.G and R.H, Strawser. 1970. "Job Preference Selection of Accounting Students." Journal of Accountancy,June, pp 84-86.

Chan, Andi Setiawan. 2012. Analisis Faktor-Faktor Yang Mempengaruhi Pemilihan Karier Menjadi Akuntan Publik Oleh Mahasiswa Jurusan Akuntansi, Jurnal Ilmiah Mahasiswa Akuntansi, Vol.1, No.1: 53-58.

Ernawati, Nina, dkk. 2013. Persepsi Mahasiswa Akuntansi Mengenai Faktor-Faktor Yang Mempengaruhi Pemilihan Karir, Jurnal Dinamika Akuntansi, Vol.5, No.2.

Felton, Sandra, Nola Buhr, and Margot Northey, 1994, "Factors Influencing The Bussiness Students' Choice of a Career in Chartered Accountancy", Issues in AccountingEducation, June, pp 131 - 141 .

Felton, Sandra, Nola Buhr, and Margot Northey, 1994. "Factors Influencing The Business Student's Choice of a Career in Chartered Accountancy”. Accounting Education, June: 131-141.

Forsyth, D. 1980. "A Taxonomy of Ethical Ideologies". Journal of Personality and Social Psychology, Vol. 39: 175-184. Forsyth, D. 1992. "Judging the Morality of Business Practices : the Influence of Personal Moral Philosophies”. Journal of Business Ethics. Vol. 11: 416-470.

Ghozali, Imam. 2016. Aplikasi Analisis Multivariate Dengan Program IBM SPSS 23 (edisi ke delapan).Semarang : Universitas Diponegoro.

Indriantoro dan Supomo. 2002. Metodologi Penelitian Bisnis Untuk Akuntansi dan Manajemen, Edisi 1, BPFE, Yogyakarta.

Komaruddin. 1994. Ensiklopedia Manajemen, Jakarta: Bumi Aksara. 
Kunartinah. 2003. Perilaku Mahasiswa Akuntansi di STIE STIKUBANK Semarang Dan Faktor-Faktor Yang Mempengaruhi Pemilihan Karir Sebagai Akuntan Publik, Jurnal Bisnis Dan Ekonomi, Vol.10, No.2: 182-197.

Meliana, Sri Agus. 2014. Faktor-Faktor Yang Mempengaruhi Pemilihan Karir Akuntan Bagi Mahasiswa Akuntansi: Universitas Maritim Raja Ali Haji Tanjungpinang.

Merdekawati, Dian Putri dan Ardiani Ika Sulistyawati. 2011. Faktor-Faktor Yang Mempengaruhi Pemilihan Karir Akuntan Publik dan Non Akuntan Publik, Aset, Vol.13 No.1:9-19.

Nugroho, Adi Putra. 2012. Persepsi Mahasiswa Akuntansi Mengenai Faktor-Faktor Yang Mempengaruhi Pemilihan Profesi Sebagai Akuntan, Journal Universitas Brawijaya, Malang.

Philip Law and Desmond Yuen. 2012. "A multilevel study of students'motivations of studying accounting: Implications for employers", Journal of Education andTraining, Vol. 54 Iss: 1 pp. $50-64$.

Prasetyo, Henri. 2014. Kajian Persepsi Pemilihan Karir Akuntan. FEB. Universitas Dian Nuswantoro. Halaman 1-20.

Putri, Eskasari dan Dharma, Arief Budhi. 2015. Faktor-Faktor Yang Mempengaruhi Pemilihan Karir Mahasiswa Akuntansi Sebagai Akuntan Publik. Seminar Nasional dan The $3^{\text {rd }}$ Call for Syariah Paper Accounting FEB UMS.

Ramdhani, Rahmat Fajar dan Zulaikha. 2013. Analisis Faktor-Faktor Yang Mempengaruhi Karir Mahasiswa Akuntansi, Diponegoro Journal of Accounting, Vol.2, No. 4: 1-13.

Rasmini, Ni Ketut. 2007. Faktor-Faktor Yang Berpengaruh Pada Keputusan Pemilihan Profesi Akuntan Publik Dan Nonakuntan Publik Pada Mahasiswa, Buletin Studi Ekonomi,Vol. 12 No.3:351-363.

Ratnawati, Vince dan Supriono. 2014. Analisis Faktor-Faktor Yang Mempengaruhi Mahasiswa Akuntansi Dalam Pemilihan Karir Menjadi Akuntan Publik. Jom FEKON Vol. 1, No.2: 1-15.

Sembiring, Simba M. 2009. Faktor-Faktor yang Mempengaruhi Pemilihan Karir Menjadi Akuntan Publik Oleh Mahasiswa Departemen Akuntansi Fakultas Ekonomi USU Medan.Tesis tidak diterbitkan. Medan: Sekolah Pasca SarjanaUniversitas Sumatra Utara.

Sulistyawati, Ardiani Ika, Nina Ernawati dan Netty Sylviana. 2013. Persepsi Mahasiswa Akuntansi Mengenai Faktor-Faktor Yang Mempengaruhi Pemilihan Karir, Jurnal Dinamika Akuntansi, Vol.5, No.2, September 2013: 86-98.

Wheeler, K. G. 1983, "Perception of Labor Market Variables by College Students in Business, Education and Psychology". Journal of Vocational Behavior, Vol. 22: 1-11. 
Wicaksono, Y,. 2010. Persepsi Mahasiswa Akuntansi Mengenai Faktor-Faktor Yang Membedakan Pemilihan Karir Profesi Akuntan, Skripsi, Semarang: Program Sarjana Fakultas Ekonomi Universitas Diponegoro.

Wijayanti, Lilies Endang. 2001. Faktor- Faktor yang Mempengaruhi Pemilihan Karir AkuntanPublik. Media Mahardika Vol. 10 No. 1.

Yendrawati, Reni. 2007. Persepsi Mahasiswa dan Mahasiswi Akuntansi Mengenai Faktorfaktor yang Mempengaruhi Pemilihan Karier sebagai Akuntan. Fenomena, Vol. 5, No. 2: $176-192$. 